\title{
Poder local e rede urbana nas minas de Goiás
}

Fernando Lobo LEMES ${ }^{\bullet}$

Resumo: Vila Boa constituiu-se em centro político e administrativo com jurisdição sobre a vasta região das minas de Goiás, durante o século XVIII. Até o início do século XIX, era a única vila em toda a capitania, cujo território encontrava-se pontilhado de arraiais, formando uma rede de pequenos centros urbanos. Desprovidos da condição de vila imperial, estes arraiais se curvavam, do ponto de vista político e econômico, ante o poder de Vila Boa de Goiás. Nesse contexto, o que nos interessa mais diretamente neste artigo são as estratégias que um centro de poder dominante utiliza para garantir as condições e o direito de sobrepor seus próprios interesses a outros centros urbanos. Funcionando como importante atrativo para as elites locais, esta condição política foi objeto de grandes esforços e intensa dedicação por parte das autoridades municipais, visando garantir a preeminência de Vila Boa sobre os arraiais existentes nas minas de Goiás.

Palavras-chave: Poder Local; Cidade Colonial; Rede Urbana; Império Português.

A historiografia atual, notadamente aquela produzida em Portugal e no Brasil, dispõe de informações sobre as minas e capitania de Goiás, quase sempre a partir de uma imagem construída através da noção de decadência (VIDAL, 2006), o que nos remete a uma construção historiográfica que assume, no mais das vezes, a descrição de uma região inóspita e quase desértica, sempre em função dos gráficos e tabelas que

- Doutorando Université Paris 3/Sorbonne Nouvelle - Institut des Hautes Études de l'Amérique Latine (IHEAL) - Paris (75000) - França. E-mail : lobolemes@hotmail.com

HISTÓRIA, São Paulo, 28 (1): 2009 
informam o declínio da produção do ouro produzido nas minas de Goiás.

Não nos cabe aqui desconstruir essa noção de decadência que, diga-se de passagem, marcou de forma significativa sua história posterior (CHAUL, 1997). Trata-se, ao contrário, de permitir ao interessado no assunto ver ao menos parte de toda a complexidade presente nas relações quotidianas de poder que tiveram lugar nas minas e capitania de Goiás, durante a segunda metade do século dezoito.

Contudo, mesmo ultrapassados os limites impostos pela imagem da decadência e, ainda assim, admitindo a pouca relevância das minas de Goiás no contexto da América portuguesa, não poderíamos ignorar a densa documentação existente a respeito de uma considerável movimentação política e econômica realizada na capitania a partir de seu principal núcleo urbano: Vila Boa de Goiás.

Diante deste quadro e considerando a vitalidade política das minas de Goiás no final do século dezoito, algumas questões podem ser colocadas. Apesar da sensível redução da produção aurífera, característica do período, e a limitada economia agropastoril, pouco atrativa devido sua baixa lucratividade, que outros fatores teriam atuado como força gravitacional, atraindo as elites locais e autoridades de nomeação régia, mantendo vivas as disputas e os interesses pela ocupação dos cargos existentes na capitania e, muito especialmente, aqueles oferecidos pela câmara municipal de Vila Boa de Goiás?

Se até mesmo os ordenados dos oficiais da câmara encontravam-se bloqueados, o que indica ausência de remuneração para juízes ordinários e vereadores ${ }^{1}$, que outros mecanismos teriam exercido força de atração para que Vila Boa de Goiás permanecesse extremamente viva enquanto espaço de disputas políticas entre os distintos grupos presentes na cidade?

Se a descrição dos viajantes europeus, comuns nas primeiras décadas do século XIX, lançam cores negras sobre o quadro econômico e social "desolador" das minas e capitania de Goiás (NUNES, 1994; CHAUL, 1997), a análise dos documentos 
que registram as relações políticas parecem destoar de tais narrativas, permitindo mesmo entrever condições bastante diversas. Esta constatação nos leva a projetar sobre a tela quotidiana de sua história a visão de uma capitania ainda recheada de atrativos.

Aparentemente, a consciência de que a câmara municipal de Vila Boa de Goiás detinha importante papel como espaço de negociação, articulação e representação no seio da monarquia portuguesa, o que emprestava peso significativo às suas decisões políticas, tornava seus cargos cobiçados entre os atores políticos, na geografia dos poderes locais.

Por outro lado, se a ênfase na atuação política da câmara municipal foi sendo, paulatinamente restringida em função das ações políticas e administrativas da coroa, o que poderia, inclusive, ter provocado uma diminuição do interesse no acesso aos ofícios municipais, a autonomia no âmbito do governo, do controle e administração da cidade, permaneceu praticamente inalterada. Desta forma, o exercício do direito de administrar a vila também teria corroborado para a manutenção de um vivo interesse das elites locais em ocupar, estrategicamente, os cargos da câmara municipal.

Mas não apenas isto. Sabemos hoje a respeito da importância da instância política e sua função nas sociedades européias modernas, já que o funcionamento de todo o mercado imperial ultramarino, seja o mercado transoceânico ou os mercados internos e regionais, tinha como referências essenciais as regras que norteavam o funcionamento das sociedades de Antigo Regime. Noutras palavras, o mercado ultramarino estava marcado fundamentalmente pela interferência da política sobre o comércio. Isso significa que o controle dos procedimentos e das instituições políticas podia conferir a possibilidade de acesso às esferas mais amplas das atividades econômicas. Assim, se dermos crédito às ações e atitudes dos protagonistas políticos das minas e capitania de Goiás, somos levados a reconhecer que eles também não ignoravam este fato. 
Distante, portanto, da noção de um mercado auto-regulado, onde seu funcionamento seria determinado pelas regras ou "leis" da oferta e da procura (FRAGOSO, 2002).

Nesse sentido, foi exatamente fazendo uso adequado do poder que detinham, que as elites políticas de Vila Boa buscaram ampliar o alcance de suas ações adicionando às estratégias que visavam o aumento de suas riquezas materiais e de seu poder político, certos mecanismos de pressão sobre as economias dos outros núcleos urbanos espalhados pelo território da capitania. Em torno desta configuração, é fundamental ampliar nossa observação, no tempo e no espaço, a fim de compreender os móveis principais que emprestavam importância aos cargos e às relações políticas tecidas nas minas de Goiás.

De fato, uma verdadeira rede urbana se abria com todas as virtuais possibilidades de domínio econômico, somando-se às demais atividades que atuavam como atrativos para os grupos políticos locais. Noutras palavras, as elites políticas de Vila Boa de Goiás detinham o controle de um centro decisivo de poder e influência baseado no modelo de organização dos poderes locais adotado nos domínios portugueses da América.

\section{A oeste do império: Vila Boa e as minas de Goiás}

Nos domínios coloniais portugueses na América, apenas com o deslocamento do eixo econômico do nordeste açucareiro para o centro-sul do continente e a descoberta de ouro e diamantes em grandes proporções é que as concentrações humanas puderam alcançar dimensões de verdadeiras redes urbanas (FONSECA, 2003). Por seu turno, também é verdade, que a transferência da capital administrativa de Salvador para o Rio de Janeiro foi, também, decorrência do desenvolvimento da economia de mineração em Minas Gerais, Mato Grosso e Goiás. Neste quadro, a descoberta de grandes jazidas de ouro desencadeou um processo de ocupação territorial que culminou 
com o domínio de toda a região central da América pelos portugueses, até a fronteira oeste, estabelecendo suas bases em Mato Grosso e Goiás, a partir de uma rede de cidades estrategicamente posicionadas.

Não podemos esquecer que, durante o século dezoito, uma dupla mutação, aponta para duas categorias de transformações que alteraram consideravelmente a fisionomia da América portuguesa: mutação espacial, resultado de uma veloz e ampla expansão territorial na colônia, principalmente no centro-sul e centro-oeste; e mutação econômica e demográfica, consequência dos descobrimentos, seguido de rápido e intenso deslocamento populacional das áreas de mineração de ouro e diamantes (MARTINIÈRE, 1991).

Do ponto de vista da coroa, as distâncias quase insuperáveis e o tempo - condicionado pelo compasso peculiar das instituições políticas e administrativas - impunham respostas necessárias aos fluxos demográficos, sociais e econômicos. À criação de novas capitanias, somou-se a necessidade de adoção de outras providências como a criação de vilas e a instalação de agentes da coroa junto aos núcleos de povoamento e extração mineral, como forma de controle e fiscalização dos direitos reais.

Percorrido e conhecido por bandeirantes desde o início da colonização da América, ocupado oficialmente por exploradores em 1725, quando se fundou o arraial de Sant'Anna, e desmembrado da capitania de São Paulo em 1749, Goiás entra na história como as Minas dos Goyazes (PALACIN, 2001: 27).

De um dinamismo populacional extraordinário, afluía para as Minas dos Goyazes uma verdadeira multidão. Dez anos após o início das atividades de mineração, já havia se instalado em Goiás cerca de 20.000 pessoas, abrindo caminhos, fundando núcleos urbanos e pondo em atividade parte significativa de seu imenso território. Já na condição de capitania de Goiás, em 1750, sua população girava em torno de 40.000 habitantes. Em 1781, de acordo com informações do governador Luis da Cunha Meneses, havia em Goiás uma população de 58.829 habitantes e, em 1783, 59.287 pessoas (PALACIN, 2001: 77). Dados coligidos 
por nós, a partir de um mapa produzido pelo governador Tristão da Cunha Meneses, em 1792, indicam uma população de 60.428 habitantes, apontando para um índice populacional ainda crescente, embora em ritmo bastante lento.

No centro dessa conjuntura demográfica, núcleo econômico e político vital, a região de Vila Boa de Goiás concentrava, em 1792, mais de $22 \%$ da população da capitania, com 13.312 habitantes, sendo 8.840 homens e 4.472 mulheres. Da população total, 8.568 se encontravam na condição de negros cativos, ou seja, mais da metade dos habitantes (64\%), indicando uma ainda persistente presença de mão-de-obra escrava, o que pode revelar uma atividade econômica de considerável expressão, mesmo na última década do setecentos.

Resultado da expansão em direção ao oeste, filha do interesse descontrolado pelo ouro, mas ao mesmo tempo, de uma mutação espacial e demográfica que conferiu novo significado às regiões centrais da América portuguesa, Vila Boa de Goiás foi pensada e planejada a partir das necessidades essenciais de manutenção e controle do império português.

Procurando compreender as razões que impeliam a ocupação territorial da América portuguesa, que se expandia cada vez mais para o oeste, Sérgio Buarque de Holanda indica como causa provável para o avanço desta fronteira a ação consciente, planejada e estrategicamente estimulada, por parte da monarquia portuguesa, combinada com a atividade prática dos habitantes da colônia, realizada de forma sistemática e contínua (GARCIA, 2003).

Associados a este movimento intencional promovido pelos colonizadores portugueses, outros dois fatores teriam alimentado os interesses que empurravam, cada vez mais para o oeste, os limites do domínio português na América: o desânimo com que os espanhóis permaneceram após a descoberta nas minas de Potosi - que pode ter facilitado a ação da coroa sobre os territórios das fronteiras delimitadas pelo Tratado de Tordesilhas - e o mito da Ilha Brasil, fator definidor do imaginário geográfico do período colonial (GARCIA, 2003). De acordo com esta configuração mitológica, haveria uma ligação 
aquática entre o norte e o sul do continente sul americano, interligando a bacia do rio da Prata à do rio Amazonas, e o Brasil, posicionado a leste desta via aquática, conformaria uma ilha, a Ilha Brasil.

De fato, através do estímulo à fundação de vilas e cidades, o rei de Portugal tratou de providenciar a consolidação de sua presença estratégica na fronteira oeste da América portuguesa, tendo a segunda metade do século XVIII assistido à ocupação da região como forma de estabelecimento das bases materiais do domínio português frente ao domínio espanhol. Após a fundação da capitania de Mato Grosso, foram criados sua primeira capital, Vila Bela e, posteriormente, os fortes de Coimbra e Príncipe da Beira, bem como as vilas de Albuquerque, Vila Maria e Casalvasco. A estratégia política determinada é evidente, pois seria justamente entre Casalvasco e Vila Maria que se localizaria o terreno onde as bacias do Amazonas e do Prata fariam, teoricamente, sua transposição (GARCIA, 2003). Assim, a iniciativa portuguesa teria estabelecido total domínio sobre esta região, fechando-a aos espanhóis.

À luz deste raciocínio, parece claro o interesse do monarca português no controle e expansão do império em direção ao oeste do continente, estimulando a ocupação estratégica deste território. Vila Boa de Goiás constituía-se, assim, num posto avançado a oeste, situado nas proximidades da linha definida pelo Tratado de Tordesilhas, que, além de atender aos interesses do governo português, enquanto centro de uma estrutura fiscal e administrativa que viabilizava a extração do ouro nas minas de Goiás, atuava como ponto de apoio estratégico - oferecendo suporte material, humano e financeiro. Ancorava, assim, na condição de uma base solidamente organizada, o avanço paulatino desta última fronteira colonial, na região oeste da América portuguesa.

Símbolo de uma nova concepção espacial urbana nas estratégias de ocupação territorial por parte da coroa, Vila Boa de Goiás não se desconectou do passado secular das cidades portuguesas, caracterizadas pela presença dos antigos concelhos de origem medieval. Unidades fundamentais de 
organização política e territorial do reino, os concelhos portugueses não sofreram alterações significativas no processo de expansão do império, nos territórios do ultramar. Governados pelas câmaras, que detinham atribuições judiciais, administrativas, militares e fiscais, podiam ser reagrupados em circunscrições mais vastas: as comarcas ${ }^{2}$.

Desta forma, não devemos menosprezar a importância de Vila Boa de Goiás no contexto do mundo luso-brasileiro. Na definição que Maria Fernanda Bicalho empresta aos contornos da cidade colonial, podemos vê-la como território de embates de projetos políticos e interesses econômicos, cenário e veículo de interlocução, núcleo ordenador do diálogo produzido com a monarquia portuguesa, cujo vértice estaria ancorado na atuação da câmara municipal (BICALHO, 2003). Espaço de convergência e representação dos interesses de grupos políticos locais, Vila Boa destacou-se como núcleo estratégico de controle por parte da coroa e, ao mesmo tempo, palco de convergência dos vários interesses em jogo no processo de colonização na fronteira oeste da América (GOUVÊA, 1998: 299).

Embora a produção aurífera não tenha disponibilizado técnicas avançadas de exploração, limitando-se à extração do ouro à superfície do solo, as relações de mercado estabelecidas nas paisagens das minas e capitania de Goiás integraram os fluxos e movimentos comerciais estabelecidos entre as regiões voltadas para o comércio ultramarino, via Oceano Atlântico, e as rotas que ligavam as vilas e cidades localizadas no interior da América portuguesa. Tratava-se de verdadeiras correntes comerciais integradas por vias de comunicação terrestres e fluviais, por onde trafegavam tropeiros, mercadores e boiadeiros dos mais diferentes pontos do Brasil, notadamente do centro-sul e nordeste, principais mercados abastecedores das áreas de mineração (FURTADO, 1999 : 199).

Neste sentido, dentre as cidades da América portuguesa, a situação de Vila Boa de Goiás, em certa medida privilegiada do ponto de vista econômico, aponta para um papel relevante no contexto do império português. Embora sua população permanecesse relativamente pequena, Mary Karasch tece uma 
consideração vigorosa sobre Vila Boa, como sendo um núcleo significante. Observa que oficiais no Tribunal de Contas em Lisboa estavam preocupados com Goiás que, em 1775, era a quinta capitania mais rica do Brasil. Vila Boa era também um centro administrativo com jurisdição sobre uma vasta região, além de um entreposto vital no comércio para Vila Bela e através dos rios Araguaia e Tocantins - para Belém. Constituíase igualmente em ponto central de mineração ao longo da década de 1790. Apesar de não ser sede episcopal, Vila Boa desempenhava um significante papel enquanto centro religioso (RUSSEL-WOOD, 1998: 22).

De fato, quando falamos de Vila Boa de Goiás, as referências não nos devem enganar: trata-se de um espaço marcado por alteridades e conflitos que excediam as fronteiras da vila enquanto núcleo espacial urbano. Até o início do século XIX, mais precisamente até 1809, foi a única vila erigida, por ordem expressa do rei, em toda a capitania de Goiás, cujo extenso território encontrava-se pontilhado por diversos arraiais (PALACIN, 1983: 56).

Essa diversidade de arraiais $^{3}$ que floresciam e gravitavam em torno das minas recebeu, antes mesmo da fundação de Vila Boa de Goiás, um aparato administrativo e judicial com o objetivo de amenizar as dificuldades provenientes da ausência de mecanismos governamentais e administrativos localizados dentro do território de exploração aurífera (PALACIN, 1983: 56).

Assim, acatando ordem do rei de Portugal para que fosse criada uma vila na região das minas, o conde de Sarzedas, Antônio Luiz de Távora, então governador da capitania de São Paulo, deslocou-se para Goiás onde, em fevereiro de 1737, reuniu os líderes políticos locais no arraial de Meia Ponte para tratar do assunto. Contudo, ao invés de "criar" a vila, de acordo com as determinações da coroa, mandou nomear, em cada um dos arraiais, dois juízes ordinários, um tabelião, um alcaide e um porteiro, sendo sua decisão confirmada dois anos mais tarde por ordem régia (SILVA E SOUZA, 1998: 84).

Este mecanismo de controle e normatização das minas de Goiás persistiu durante o século dezoito e início do seguinte, 
permanecendo aparentemente intocado, definindo a forma de organização judicial e econômica a partir de um sistema de julgados, enquanto circunscrições judiciárias incompletas e sem autonomia administrativa, conformando a base de uma rede urbana cujo domínio e soberania foi transferida para Vila Boa de Goiás, dois anos depois, em 1739, com a instalação da câmara municipal.

Sistema utilizado pela administração colonial em Goiás, a multiplicação dos julgados no âmbito da capitania, ancorado numa espécie de pequenos governos municipais que, por sua vez, mantinham sob sua jurisdição vários outros arraiais, tornaria a situação de Vila Boa de Goiás excepcionalmente vantajosa (PALACIN, 1983 : 56). Por ser o único centro urbano com estatuto de vila colonial, agregava em torno de si uma vasta rede de núcleos populacionais, impondo e garantindo seu controle nas mais diversas instâncias submetidas aos oficiais municipais.

Vale lembrar que, na América portuguesa, os lugareschefes dos concelhos eram aglomerações autônomas que recebiam o título de vila, possuindo governo próprio, uma câmara e um território sob sua jurisdição. Para melhor compreender o conjunto urbano que integrava a rede de arraiais governados pela câmara municipal de Vila Boa de Goiás, convém esclarecer a distinção existente entre concelhos e vilas, já que nos registros contemporâneos as referências a estas duas palavras podem, às vezes, emprestar-lhes significados muito parecidos.

Se o concelho é constituído pela vila - núcleo urbano sede da câmara municipal - e seu termo - território submetido à autoridade dos oficiais municipais, que poderia incluir várias localidades distintas - a concepção de vila, por sua vez, refere-se às duas dimensões espaciais definidas pelo modelo português de organização do espaço municipal: o termo e o rossio. Neste caso, o termo da vila corresponde ao território sob a jurisdição da câmara que, no caso de Vila Boa de Goiás, incluía todo o espaço geográfico da capitania e seus núcleos urbanos. O rossio, patrimônio ligado mais diretamente à propriedade municipal 
concedida pela coroa, compunha-se de uma região de menor tamanho, tendo como ponto de referência o próprio centro arquitetônico da vila, estendendo-se até os arredores de sua aglomeração urbana (FONSECA, 2003: 21-22).

De acordo com Fernand Braudel, o território próximo da cidade não é senão o primeiro dos inúmeros círculos que a envolvia, o que confirma que a vida urbana estava ligada a uma organização hierárquica de espaços com diversas dimensões (BRAUDEL, 1979: 443). Ora, no nosso caso específico, esta variedade de cenários requer uma visão de conjunto com o objetivo de compreender as forças em jogo nas relações entre núcleos urbanos distintos, mas conectados por interesses comuns.

Em Goiás, a imagem de uma rede de cidades integradas parece ter sido determinante na definição das regras do jogo, cuja hierarquia permitia a um centro de poder dominante assumir a condição e o direito de acessar e sujeitar, de uma forma ou outra, a economia e a vida de outros núcleos urbanos, em função de suas próprias complacências e fragilidades. Para os objetivos deste estudo, trata-se de saber como essa rede de conjunto autorizava o domínio regular de uma cidade sobre as outras (BRAUDEL, 1979: 223), ou seja, despojadas da condição de vila imperial, os núcleos urbanos da capitania de Goiás curvavam-se, do ponto de vista da dominação política e econômica, ao centro desta vasta rede, à alta torre de controle, localizada em Vila Boa de Goiás.

Além disso, a existência de aglomerações interligadas implicava necessidades mais amplas que apenas poderiam ser satisfeitas a partir de um círculo de núcleos urbanos secundários no interior do território que correspondia à circunscrição de Vila Boa de Goiás. Não podemos nos esquecer, por outro lado, que Vila Boa também integrava uma rede urbana, a partir de uma escala mais ampla, constituída de outros centros urbanos, tais como o Rio de Janeiro, Belém, São Paulo, Vila Rica, Salvador e Recife que, por sua vez, formavam entre eles outra dimensão de rede, conectada, por sua vez, com diferentes regióes e 
continentes, dentro e fora dos limites geográficos do império português.

Nestes termos, do ponto de vista econômico, as diversas conexões que davam forma a uma economia mundial, interligando, inclusive, as grandes cidades européias, animavam, em última instância, as redes urbanas existentes na América portuguesa e, por extensão, a vila e os arraiais no interior dos contornos das minas e capitania de Goiás.

\section{Câmara municipal: o discurso político e a ação administrativa}

Do ponto de vista dos poderes locais, é importante esclarecer a forma como a câmara municipal de Vila Boa exercia um domínio sobre a rede urbana existente nas minas de Goiás. Para isso, fizemos uma opção metodológica que pressupõe certa cautela em relação às fontes que utilizamos. A partir da constatação de que uma dupla estratégia orientava suas articulações - uma que contemplava os direitos da câmara municipal nos espaços de sua jurisdição e, outra, que remetia às ações, propriamente ditas, de controle sobre a rede urbana identificamos certa unidade que empresta coerência e torna compreensível as atividades e iniciativas dos oficiais municipais.

Num primeiro momento, uma rápida análise de suas práticas discursivas nos deixam entrever as dificuldades de gerenciamento da rede urbana, a partir de Vila Boa de Goiás, em meio às disputas políticas locais. Práticas discursivas ou, noutras palavras, argumentações políticas, que nos oferecem uma compreensão apenas parcial das funções exercidas pela câmara municipal sobre o tecido urbano da capitania.

Contudo, ao deslocar nossa análise, redirecionando o olhar para as ações administrativas, ou seja, para suas práticas nãodiscursivas, a compreensão sobre a relação entre Vila Boa e os demais núcleos urbanos parece se completar, permitindo-nos identificar o conjunto das estratégias utilizadas pelos oficiais municipais. 
Do nosso ponto de vista, esta abordagem teria o mérito de revelar os bastidores de um intricado jogo político e administrativo em que a fragilidade aparente, revelada nas práticas discursivas, visando demarcar os privilégios da câmara de Vila Boa de Goiás, alimentava e garantia o exercício prático de sua soberania, de seu governo, sobre toda a rede urbana da capitania.

Assim, a interação entre o discurso político e a ação administrativa, entre as práticas discursivas e não-discursivas, convida-nos a desvendar as intenções mais ou menos aparentes e perceptíveis nas iniciativas dos oficiais da câmara municipal de Vila Boa de Goiás.

\section{A prática discursiva}

Embora toda a organização municipal se materializasse de forma bastante clara, a condução dos procedimentos para a sua administração mereceu acurada dedicação das autoridades municipais para que fosse garantida a preeminência de Vila Boa sobre os arraiais das minas de Goiás. Pouco tempo depois de instalada a vila, uma carta do então governador da capitania de São Paulo já revelava as dificuldades para se garantir a submissão dos núcleos urbanos à autoridade de Vila Boa, antecipando os embates travados pelos oficiais da câmara para a garantia deste privilégio. D. Luiz de Mascarenhas, em 2 de outubro de 1739, denunciava ao rei de Portugal o fato de juízes ordinários dos arraiais das minas de Goiás não cumprirem os mandatos e as determinações da câmara municipal. Em resposta à informação do governador, um ano e meio mais tarde, D. João $\mathrm{V}$ reafirmava a importância da hierarquia existente no tecido urbano das minas de Goiás, insistindo na necessidade de sujeição de todos os demais arraiais ao comando de Vila Boa de Goiás, já que era a única vila existente em toda a capitania (AHU, CX. 36, D. 2198).

Cerca de quarenta anos depois, as dificuldades em fazer cumprir aquela determinação da coroa ainda preocupava os 
oficiais da câmara municipal. Uma espécie de "perturbação" na ordem das coisas, para usar um termo muito presente nos discursos da época, fez com que a câmara de Vila Boa tentasse mobilizar instrumentos de controle, cerceando as autonomias e liberdades das autoridades localizadas em cada arraial, impondo, assim, sua prerrogativa em governar, direta ou indiretamente, todos os núcleos urbanos existentes na capitania.

Assim, expondo suas inquietações quanto ao problema e reivindicando "as liberdades, graças e merces", que o rei de Portugal havia deliberadamente conferido a Vila Boa de Goiás, os mesmos oficiais da câmara acusavam o rompimento de uma rotina indispensável para $\mathrm{o}$ bem estar de todos. Tal rotina estaria sendo perturbada, segundo eles, por iniciativa daqueles que deveriam, em todas as circunstâncias, observar a consecução das ordens reais (AHU, CX. 36, D. 2198). A partir desta argumentação, buscando reforçar e tornar mais favorável sua posição como depositária fiel das determinações do monarca, encaminhou, em 1779, para cada um dos núcleos urbanos das minas de Goiás, uma "Carta de Diligência" dirigida a todos os juízes ordinários dos arraiais, alertando-os acerca do fato de que os rendimentos de todos os julgados da comarca estavam sob sua única e exclusiva responsabilidade e poder (AHU, CX. 36, D. 2198).

Entretanto, quatro anos depois, sem alcançar o efeito esperado, aparentemente impossibilitados de exercer o controle desejado sobre os julgados, que deveriam estar sob seu comando e, certamente, assistindo aos desvios e descaminhos das receitas que, por decisão do rei de Portugal, pertenceriam à câmara de Vila Boa de Goiás, uma vez mais o juiz ordinário e os vereadores da cidade demonstraram seu descontentamento. Desta vez, buscando claramente ampliar seu poder de ação, somando aos seus instrumentos de controle a força política do governador da capitania, recorreram a Luiz da Cunha Meneses.

Alegando caber ao governador a autoridade e a competência de fazer com que as ordens do rei de Portugal fossem executadas dentro da capitania e, especialmente, aquelas em benefício de Vila Boa de Goiás, tentaram sensibilizar 
Cunha Meneses na tentativa de atraí-lo para a defesa das mesmas causas propostas pelos oficiais municipais. Através de uma correspondência densa, elegante e bem redigida, racionalmente estruturada, solicitaram a intervenção do governador para o cumprimento das determinações reais e, principalmente, para fazer com que todas as receitas e despesas realizadas pelos juízes ordinários dos arraiais da comarca passassem pela supervisão da câmara de Vila Boa (AHU, CX. 36, D. 2198).

Aparentemente, a carta ao governador Cunha Meneses permaneceu sem resposta, nem sequer um gesto que pudesse revelar sua concordância com a solicitação feita pela câmara municipal. Ao que tudo indica, as liberdades, graças e a mercês de Sua Majestade faziam água por todos os lados e a supervisão e o controle por parte da câmara de Vila Boa sobre a economia dos demais núcleos urbanos pareciam se efetivar apenas parcialmente.

Assim não fosse, não haveria a necessidade de, uma vez mais, recorrer à autoridade de outro governador, a esta altura o irmão e sucessor de Luiz da Cunha Meneses. Nesta nova tentativa para convencer o governador da capitania, uma carta foi dirigida a Tristão da Cunha Meneses com uma longa exposição de motivos. Junto dela foi anexada uma cópia da carta enviada ao governador anterior, bem como cópia da provisão de D. João V, dirigida a D. Luiz Mascarenhas, no ano de 1741, na qual o rei se manifestava pessoalmente a respeito dos direitos e soberania da câmara de Vila Boa de Goiás.

Buscando sensibilizar o governador, além de reforçar as denúncias expostas nas correspondências anteriores, desta vez os oficiais municipais, representados na carta por seu procurador, indicavam claramente a existência de culpados pelos frequentes "desvios" dos recursos provenientes dos arraiais da capitania.

Sentindo, certamente, a existência de um flanco aberto no tabuleiro das finanças municipais, os oficiais da câmara exorcizavam os interesses de ouvidores e corregedores, descrevendo-lhes o papel que lhes cabia na arquitetura 
administrativa da monarquia portuguesa. Diziam, textualmente, que à jurisdição dos ouvidores e corregedores estava reservado apenas o poder de examinar as despesas da câmara, verificando possíveis irregularidades e tomando as providências cabíveis em cada caso.

Em seguida, após acusar os corregedores de exercer de modo fraudulento o controle das finanças dos arraiais e de usarem de forma arbitrária os rendimentos dos "concelhos", enfatizaram o "lugar" em que deveriam permanecer os oficiais régios, qual seja, dentro dos limites de suas próprias jurisdições, abstendo-se, portanto, de tocar, nas receitas que deveriam ser administradas pela própria câmara, afirmando, ainda, que não teriam competência alguma para promover a arrecadação, nem, muito menos, "a ingerencia na administração das mesmas rendas nem a livre dispozição dellas em todo ou em parte, como alguns tem feito" (AHU, CX. 36, D. 2198).

Apesar da persistente mobilização dos oficiais municipais e do embasamento lógico de suas reivindicações, Tristão da Cunha Meneses, impossibilitado de apresentar qualquer solução para a solicitação da câmara, cuja dimensão parecia extrapolar os limites de sua jurisdição e de seu poder, achou por bem encaminhar o problema à rainha de Portugal. Em 1786, em carta dirigida à D. Maria I, discorria acerca do deficiente método de administração e arrecadação das rendas da câmara de Vila Boa e apresentava sugestões pessoais para sua solução (AHU, CX. 36, D. 2198).

Vale ressaltar que essa movimentação promovida por parte dos oficiais da câmara municipal, na tentativa de consolidar ou mesmo restabelecer privilégios concedidos no passado, integravam suas iniciativas no âmbito dos discursos que compunham os embates políticos, marcados por interesses divergentes, entre autoridades e grupos de poder locais. Tais embates seguiam sempre uma linha definida pelas características e natureza das relações de poder próprias às sociedades de Antigo Regime.

Contudo, se nos espaços discursivos de suas ações, no âmbito da defesa política de seus privilégios, o controle efetivo 
de uma rede de arraiais parecia tropeçar nos obstáculos quase intransponíveis que encontrava, a câmara de Vila Boa de Goiás parece não ter sofrido as mesmas oposições no exercício quotidiano do governo e da administração dessa mesma rede urbana. Exercício garantido por um antigo privilégio: o direito de almotaçaria.

\section{A prática não-discursiva}

Apesar da inexistência de documentos como os Livros de Provimentos dos Ouvidores ou os Termos de Audiências dos Almotacés, que nos poderiam revelar com mais detalhes a realidade urbana colonial, as fontes das quais dispomos para Vila Boa, que registram a prática do direito de almotaçaria ${ }^{4}$, permitem-nos detectar com bastante clareza aspectos importantes a respeito da sociabilidade quotidiana, do pensamento sobre as formas possíveis de organização sócioespacial da cidade e sua configuração econômica.

Embora não seja nosso objetivo voltar nossa atenção às origens da instituição da almotaçaria, convém identificar alguns aspectos pontuais de sua genealogia. $\mathrm{Na}$ cidade muçulmana, $\mathrm{o}$ almotacé era o responsável pela Hisba (em árabe, o titular da Hisba era denominado Muhtasib), cujas funções eram a aferição dos pesos e medidas, o equilíbrio nas transações comerciais, o controle dos ofícios urbanos, a garantia do abastecimento alimentar, a higiene e sanidade urbana e a manutenção dos aspectos físicos da cidade. Mais tarde, quando incorporado na tradição municipal portuguesa, o cargo de almotacé foi mantido, mesmo após a reconquista, como forma de manter o controle administrativo e econômico dos núcleos urbanos (PEREIRA, 2001: 392).

Em Portugal, muito cedo - a partir de 1179 -, as câmaras municipais passaram a eleger os almotacés, havendo a padronização deste poder de escolha, a partir do século XIII, o que o transformou em oficial de nomeação da municipalidade. Com a constituição do império, as atribuições dos almotacés - o 
controle do mercado, do sanitário e do construtivo - foram preservadas nas regiões coloniais, atingindo todo o universo urbano português, sendo o regimento dos almotacés incorporado nas Ordenações Manuelinas e, mais tarde, nas Ordenações Filipinas.

Durante o Antigo Regime, o instituto da almotaçaria tomou forma, se adequando às estruturas de um sistema corporativo no qual o poder político era representado enquanto articulação de múltiplos círculos ou núcleos autônomos de poder. Neste contexto, a sociedade era considerada como um grande corpo, cuja cabeça seria o rei. Desta forma, a cidade também teria sua cabeça, representada pelas comunas ou câmaras que, por sua vez, conviveria com outros corpos menores como o clero, as corporações de ofício, as famílias e seus cidadãos ou moradores (PEREIRA, 2001: 378).

Cabeças das cidades, as câmaras coloniais, depois de integrá-las nas malhas de sua estrutura administrativa, tratariam logo de submeter ao seu controle as funções relativas à almotaçaria. No caso de Vila Boa de Goiás, suas atribuições foram sendo absorvidas pela câmara municipal, que assumiu o papel de agente responsável pela almotaçaria no interior das fronteiras de sua jurisdição.

Assim, responsáveis pela manutenção da higiene, pelo controle das demandas relativas à edificação e construção, bem como pela fiscalização das relações de mercado (ORDENAÇÕES FILIPINAS, 1990: 1-42), a câmara de Vila Boa de Goiás estendia seu controle por toda a malha urbana que a circundava. Prova disso são os textos das atas que registram as reuniões semanais dos oficiais municipais, através das quais podemos perceber a existência de um controle quase implacável sobre a vida e as finanças dos núcleos urbanos espalhados pelas minas e capitania de Goiás.

Dividida em duas regiões principais, sendo Vila Boa sede da comarca do sul e São João das Duas Barras, sede da comarca do norte, a capitania de Goiás estava constituída, durante o século dezoito, por 14 julgados, sete em cada região. Os sete julgados do norte eram Porto Real, Natividade, Conceição do 
Norte, Arraias, São Félix, Cavalcante e Traíras. Os sete da comarca do sul eram Crixás, Pilar de Goiás, Meia Ponte, Santa Luzia, Santa Cruz, Araxá e Desemboque (ROCHA, 2001).

Além disso, arraiais como Porto Real, Pontal, Monte do Carmo, Chapada, Almas, São José do Duro, Arraias, Monte Alegre, São Domingos, São Felix, Cavalcante, Amaro Leite, São José do Tocantins, Cachoeira, Muquém, Flores, Água Quente, Rio Claro, Anicuns, Mossâmedes, Curral, Jaraguá, Santo Antônio do Descoberto, Formosa, Bonfim, Santa Cruz, Crixás, Pilar, Anta, Ferreiro, Tesouras, Santa Rita, Meia Ponte, Ouro Fino, Barra, Natividade, Santa Luzia, Trahiras, Dezemboque e Conceição do Norte faziam parte de uma diversidade de núcleos urbanos, como pontos equidistantes de uma rede interligada e governada a partir da autoridade da câmara de Vila Boa de Goiás.

Nesse contexto, a hegemonia dos interesses dos oficiais municipais decorria do controle exercido sobre as diversas atividades ligadas ao direito de almotaçaria. Direito que, além de consolidar o predomínio político das elites de Vila Boa de Goiás, respaldava as intervenções e a fiscalização sobre praticamente todas as necessidades das populações, atingindo de forma significativa todos os aspectos daquilo que Magnus Pereira denominou de "três agendas do viver urbano" (PEREIRA, 2001: 377).

São inúmeros os mecanismos adotados e várias as atividades levadas a cabo no dia-a-dia da câmara municipal que indicam o exercício de seu poder sobre a vida da população dos diversos arraiais: conservação e construção de equipamentos de uso comum, pagamento de funcionários, exercício da justiça e segurança públicas, abastecimento e controle da qualidade dos alimentos.

Exemplo deste exercício de poder foi a autorização dada pela câmara municipal ao juiz ordinário do julgado de Santa Cruz, para a realização de alguns serviços urbanos, como a recuperação da Rua Direita, a construção da ponte sobre o ribeirão da Água Suja e a recuperação dos muros do prédio da cadeia. Quanto à Rua Direita, a câmara determinou que o juiz fizesse as possíveis diligências para que o serviço fosse 
arrematado, via licitação pública, ou que se fizesse por conta do próprio julgado, até o valor de cinquenta oitavas de ouro. Com relação à ponte, autorizaram sua construção limitando, porém, as despesas até o valor máximo de trinta e duas oitavas (LIVRO DE REGISTRO DO SENADO DA CÂMARA - LRSC, 1792 : fls. 7171v.). Deram orientações, também, para a edificação e o conserto dos muros da cadeia. $\mathrm{Na}$ verdade, tratava-se da contratação de serviços cuja realização de despesas deveria ser autorizada diretamente pelos oficiais municipais em Vila Boa de Goiás, mesmo estando os recursos disponíveis no arraial onde se encontravam os problemas.

Tal relação de sujeição do julgado de Santa Cruz à câmara municipal sedimentava a posição de Vila Boa, estabelecendo uma ligação política e administrativa de domínio desta última sobre o primeiro. Se estendermos este modelo de conexão aos restantes núcleos urbanos da capitania, veremos tecidas as relações que dão forma a uma verdadeira rede de arraiais, cujo centro ou vértice político e administrativo estava estabelecido em Vila Boa de Goiás.

Caso muito parecido com este é o que revela uma carta dirigida à câmara municipal, de autoria do juiz ordinário e do procurador do julgado de Traíras, recebida em março de 1793. Nela, os dois representantes solicitavam autorização para realização de despesas, tendo em vista o conserto de várias pontes na estrada real. Após a análise do documento, os oficiais da câmara pediram alguns esclarecimentos a respeito das obras, tais como: quais eram exatamente as pontes, que tipo de conserto seria necessário e qual o valor aproximado despendido nos serviços, para que, de posse destas informações, pudessem tomar as decisões que julgassem adequadas (LRSC, 1793: fl. 88).

Evidentemente, apesar da urgência para a consecução de alguns serviços, as autoridades localizadas no julgado deveriam aguardar a autorização proveniente de Vila Boa para dar andamento às suas atividades, o que aponta para uma autonomia bastante reduzida e limitada no âmbito de suas atribuições. 
Como as obras realizadas nos arraiais eram, em sua maioria, licitadas publicamente e arrematadas por executores privados, estes processos também eram supervisionados pela câmara, o que fazia com que os juízes ordinários dos julgados ficassem obrigados a enviar, todos os meses de janeiro, certidões contendo os valores das licitações realizadas em suas respectivas jurisdições (AHU, Cx 36, D. 2198).

Este foi, sem dúvida, o caso do juiz ordinário e do procurador de Traíras, bem como do juiz ordinário de São Félix, que enviaram à câmara municipal, em junho de 1793, as certidões das propostas e lances concernentes aos consertos das "pontes e caminhos das estradas daquelle Julgado" (LRSC, 1793 : fl. 97v). Este expediente, que favorecia notavelmente o controle dos serviços e das rendas locais, permitia a elaboração de um quadro mais amplo da situação em cada região, orientando as estratégias utilizadas por parte dos oficiais municipais.

Neste mesmo cenário, outros exemplos que confirmam a soberania da câmara de Vila Boa nas minas e capitania de Goiás são encontrados fartamente. Um deles foi a resposta dos oficiais municipais ao requerimento do carcereiro do julgado de Pilar de Goiás, que pedia o valor correspondente a vinte e quatro oitavas de ouro para aquisição de azeite para a iluminação da cadeia pública. Reconhecendo a justeza da solicitação, a câmara municipal demonstrava seu interesse em adequar os gastos de manutenção com suas receitas, concedendo ao carcereiro a possibilidade de despender, ao invés das vinte e quatro oitavas solicitadas, apenas e tão somente dez oitavas de ouro (LRSC., 1792: fl. 72).

Mas, a iluminação das cadeias públicas não era a única responsabilidade da câmara de Vila Boa com relação à segurança e a execução da justiça. Neste aspecto, além de ser uma das atribuições da câmara, os oficiais municipais detinham o enorme poder de criar e reproduzir pequenas instituições responsáveis pela administração da justiça nos arraiais da capitania. É este o caso do juiz de vintena. Vale ressaltar que os juízes de vintena, previstos e autorizados pelas Ordenações Filipinas, eram os magistrados das aldeias e julgados nomeados 
pelas autoridades camarárias das vilas, "provindo-lhes o nome de Vintena (vigésima parte), do menor número de indivíduos sujeitos à sua jurisdição, em causas de mínima importância" (ORDENAÇÕES FILIPINAS, 1990: 73).

A nomeação de juízes de vintena parece ter sido parte das atividades quotidianas dos oficiais municipais. Indicativo deste fato foi o requerimento apresentado pelo procurador da câmara de Vila Boa, em 1793. Alegando que o arraial de Ouro Fino era palco de abusos e desordens que perturbavam o bem estar de seus habitantes e como havia fugas muito freqüentes de escravos (situação agravada pela inexistência de oficiais de justiça e pela distância de Ouro Fino em relação a Vila Boa de Goiás, o que tornava mais dispendioso a execução dos processos e a promoção da justiça), solicitou a nomeação de um juiz e um escrivão de vintena para o arraial (LRSC, 1793: fl. 84v). Tendo em vista os argumentos do procurador, os oficiais da câmara não hesitaram: nomearam Simão Pereira e Francisco de Souza para os cargos de juiz de vintena e escrivão, respectivamente (LRSC, 1793: fl. 98v).

O papel de mediadores entre diferentes arraiais também concedia grande destaque à posição da câmara municipal no controle de uma rede urbana organizada a partir de uma hierarquia bem definida, cujas regras deveriam ser constantemente lembradas e reforçadas.

Assim, como os moradores do arraial de Bonfim estavam juridicamente submetidos ao julgado de Santa Cruz, encaminharam requerimento à câmara de Vila Boa, solicitando que determinasse aos juízes ordinários daquele julgado a construção de um edifício para a cadeia pública e a instalação de um tronco para "castigo dos malfeitores e vadios", acusando a existência de crimes que, com frequência, ficavam sem qualquer tipo de punição. Incomodados com a insegurança em que estavam vivendo os habitantes de Bonfim e considerando a responsabilidade do julgado de Santa Cruz, os oficiais municipais concordaram de imediato com a solicitação, determinando a construção da "dita Cadea, e Tronco" (LRSC, 1793: fl. 98v), sendo as despesas pagas com os rendimentos do 
julgado de Santa Cruz. Desta forma, vemos que a viabilidade de transferência de recursos de um arraial para outro, ou seja, de um ponto a outro da rede, era um expediente que o recurso às autoridades de Vila Boa tornava possível.

Noutras palavras, o poder dos oficiais da câmara municipal parece não ter sido exercido apenas em função da concentração de riquezas em proveito de Vila Boa de Goiás. Ao contrário, seu poder era exercitado de acordo com as demandas oferecidas em toda a extensão de uma rede de núcleos urbanos interligados e interdependentes, cujo equilíbrio e manutenção eram, eles próprios, os principais responsáveis. Tal condição parece autorizar uma interpretação das atividades da câmara de Vila Boa de Goiás, como parte integrante da estrutura administrativa da monarquia portuguesa, a partir da noção de "État du bienêtre" proposta por Pierre Bourdieu (BOURDIEU; CHRISTIN \& WILL, 2000). Assim, no comando de uma rede interligada de núcleos urbanos, como agente legítima da monarquia, administrava a justiça, conservava a paz, promovia a manutenção da ordem, do conforto e da segurança da população das minas de Goiás.

Além da administração da justiça, do controle sobre a execução de obras e licitações, da construção e manutenção de edifícios públicos, da preservação da segurança e tranquilidade da população, outros tipos de intervenções confirmavam a soberania de Vila Boa sobre os arraiais das minas de Goiás. Como a câmara municipal se apropriava dos rendimentos de outros núcleos urbanos, era comum que outras localidades assumissem dívidas e obrigações contraídas pelos oficiais municipais de Vila Boa de Goiás. Foi o que aconteceu, por exemplo, numa reunião de vereadores em outubro de 1792. Como estavam vencidos os "soldos" do ajudante do segundo regimento da cavalaria auxiliar, no valor total de quatrocentas oitavas de ouro, os oficiais municipais determinaram que a dívida fosse paga pelos julgados de Pilar e Crixás, cada um assumindo o valor de duzentas oitavas de ouro (LRSC, 1792: fl. $75 v)$. 
São vários os casos que confirmam a gestão das receitas dos arraiais através do pagamento de dívidas e obrigações contraídas em Vila Boa de Goiás. Para se ter uma ideia da frequencia com que este expediente era utilizado, numa única reunião, a de 17 de maio de 1794 (LRSC, 1794: fl. 135), foram expedidas seis ordens de pagamentos. Quatro para oficiais militares e duas para saldar compromissos contraídos com o próprio escrivão da câmara municipal. Das seis ordens, duas para o sargento-mor Álvaro José Xavier da Silva, foram encaminhadas para os julgados de Traíras e Natividade; duas para o ajudante Fernando Jozé Leal, para o julgado de Pilar e Crixás; e duas para o escrivão municipal, sendo encaminhada uma ordem de pagamento para o julgado de Santa Cruz e outra para o julgado de Santa Luzia. Curiosamente, no ano anterior, o escrivão da câmara já havia sido pago, utilizando-se o mesmo mecanismo de transferência de rendas na malha urbana das minas de Goiás. Até mesmo prestadores de serviços ou arrematores de contratos, como vemos, podiam, eventualmente, ser pagos pelas rendas de outro julgado.

Outra estratégia de intervenção bastante invasiva na vida dos arraiais foi o expediente das correições. Os Termos de Correições, registrados nos livros de atas da câmara de Vila Boa, compõem-se de narrativas que transcrevem o processo de fiscalização, realizado periodicamente, referente aos vários aspectos de controle sobre vida urbana, exercida pela municipalidade através do direito de almotaçaria.

Em Vila Boa de Goiás, nada escapava aos olhos das autoridades municipais: conflitos entre vizinhos; calçadas irregulares, que provocavam a queda de pedestres; caminhos e ruas mal conservados; águas empossadas, prejudiciais à saúde dos moradores; estabelecimentos comerciais sem a devida licença de funcionamento; pesos e medidas irregulares e fora dos padrões estabelecidos; oficiais mecânicos sem carta de exame; preços de produtos em desacordo com o valor estabelecido oficialmente; ação de atravessadores ou intermediários, proibidos de atuarem pela vigência de uma economia moral que impunha suas regras ao mercado local. 
Todos eram notificados e convocados a comparecerem à sede da câmara, sob pena de serem condenados à revelia, sempre de acordo com as posturas municipais.

É bem verdade que os habitantes de Vila Boa de Goiás não eram os únicos a experimentar a normatização imposta pela câmara municipal. Sobretudo porque o espaço visado pelos oficiais da câmara se alargava na medida em que o controle sobre a malha urbana da capitania se impunha e integrava, invariavelmente, a agenda e as preocupações dos gestores municipais. Assim, assistimos claramente a ação da câmara de Vila Boa, ao observar o mesmo expediente das correições repetido em todo o circuito urbano de Goiás setecentista. Prova disso, foi o que aconteceu na reunião de 15 de novembro de 1792, em que os oficiais municipais notificaram o almotacel e tenente Francisco Soares da Sylva, para que providenciasse a realização de correições nos arraiais de Ouro Fino, Anta, Barra e Santa Rita (LRSC, 1792: fl. 78).

Notamos, assim, o pleno vigor, já na última década do século XVIII, da instituição da almotaçaria, submetendo às regulamentações das posturas municipais o movimentado quotidiano urbano das minas e capitania de Goiás, revelando, na expressão proposta por Magnus Pereira, uma consciência específica de cidade (PEREIRA, 2001: 389). Consciência que tecia e mantinha, sob o controle da câmara municipal de Vila Boa de Goiás, uma ampla rede de arraiais.

A soberania exercida sobre a rede que se projetava sobre o território da capitania, garantia, também, o controle sobre o abastecimento e a oferta de carnes nos mercados consumidores locais. Além de controlar nos mercados de Vila Boa de Goiás a concessão do oferecimento de carne à população - comércio lucrativo que certamente atraía os interesses de negociantes coloniais - a câmara municipal monopolizava o mesmo serviço em vários outros arraiais. Nesta área, Goiás experimentava significativa expansão, sendo autossuficiente na produção de carnes e, ao que parece, assumindo papel de relativa importância no mercado colonial, tendo sido uma das regiões fornecedoras de gado para o Rio de Janeiro, durante a primeira 
década do século XIX, apesar da distância e da precariedade das vias e meios de transporte (GOUVÊA, 2000: 138).

Neste ramo de atividade, que intensificava as relações regionais, aproximando grupos de negociantes que atuavam na região fluminense com os setores mercantis estabelecidos nas capitanias de Minas Gerais, São Paulo, Rio Grande (GOUVÊA, 2000: 135) e, em menor escala, Goiás, promovendo a articulação de uma rede de interesses interligados que envolvia vários pontos de passagem de gado em toda a extensão sul e sudeste da América portuguesa, os oficiais da câmara de Vila Boa de Goiás participaram ativamente.

Se uma verdadeira malha de interesses se constituía nas relações entre capitanias, outra se formava, sob o controle da câmara, no interior da rede interligada de arraiais nas minas de Goiás. Embora transferida para a iniciativa de empreendedores particulares, os processos de licitação para o fornecimento de carne, em todos os arraiais, eram submetidos ao crivo dos oficiais municipais (LRSC, 1793: fl. 103v).

Todo este controle exercido sobre a vida urbana em Goiás, que demonstra o domínio de Vila Boa a partir da ação de seus oficiais municipais, exigia para seu funcionamento um aparato jurídico e administrativo que, provavelmente, a câmara não dispunha. Provêm, certamente, daí as dificuldades em fazer valer os privilégios, as mercês e as graças concedidas pelo rei de Portugal, sendo obrigados a conviver com os eventuais e inevitáveis desvios de recursos, atrasos nos pagamentos e resistências, supostamente comuns, impostas por parte de juízes ordinários nos arraiais e de autoridades de nomeação régia.

Como estratégia utilizada para reduzir ao máximo os prejuízos da municipalidade, suprindo a deficiência dos métodos de arrecadação e controle e, ao mesmo tempo, como alternativa encontrada para pressionar os devedores, cobradores oficiais percorriam toda a extensão dos caminhos da capitania, na tentativa de regularizar os repasses e as dívidas a favor da câmara de Vila Boa de Goiás. Foi este o motivo do périplo de Manoel Seixo de Britto, funcionário e emissário oficial que, no 
mês de junho de 1793, partia de Vila Boa para uma longa jornada, em visita aos julgados da capitania.

Levando consigo cartas circulares para os juízes ordinários, solicitava que entregassem o ouro recebido nos arraiais sob cada jurisdição, requeria o apoio necessário para que obtivesse êxito na cobrança de devedores e, inclusive, que acertassem as dívidas correspondentes aos repasses não realizados nos anos anteriores (LRSC, 1793: fl. 98v). Após uma viagem que durou dez meses, o retorno de Seixo de Britto não parece ter sido objeto de frustração por parte dos oficiais municipais, pois trazia consigo a quantia equivalente a duas mil setecentas e sete oitavas de ouro (LRSC, 1793: fl. 131v). Aliás, valor expressivo se considerarmos as sucessivas quedas na produção global de ouro nas minas de Goiás.

\section{Considerações finais}

Quando analisamos a situação econômico-financeira das minas de Goiás, somos levados a concordar com Nuno Gonçalo Monteiro que, tanto no reino de Portugal, quanto em suas distantes regiões de conquistas, "os rendimentos municipais eram pouco elásticos" (MONTEIRO, 1993: 323). Naquelas minas, o aperto financeiro, como vimos, fazia parte do cotidiano da vida municipal. Mesmo havendo alguma renda, os compromissos não eram poucos. Eram inúmeros, aliás. Se, por um lado, percebemos claramente o esforço da municipalidade na preservação dos seus privilégios, por outro, eram recorrentes as cobranças por parte dos credores da câmara de Vila Boa. Além disso, os interesses pessoais e corporativos de governadores e ouvidores, argumentando, quase sempre, que as receitas da câmara eram maiores que suas próprias necessidades, apropriando-se dos recursos disponíveis e impondo condições para a realização de certas despesas, funcionavam como mecanismos de pressão contra os gestores da cidade.

Mas, visto de outro ângulo, nem tão parcos e nem tão pouco elásticos eram os rendimentos da câmara, que não 
pudessem atender a outros interesses no distante reino de Portugal: até mesmo um secretário do Conselho Ultramarino, Joaquim Miguel Lopes de Lavre, era remunerado pelas rendas da câmara de Vila Boa (LRSC, 1793: fl. 133v). Neste sentido, de uma forma geral, as minas e capitania de Goiás eram bastante visadas pelas autoridades do reino como fonte alternativa de recursos financeiros. Exemplo esclarecedor, foi o requerimento encaminhado por Domingos Vandelli ${ }^{5}$ ao príncipe regente, solicitando a concessão de donativo anual a seus filhos, proprietários que eram dos ofícios de escrivão da ouvidoria de Goiás (AHU, CX 43, D. 2596). Mesmo porque, se compararmos as rendas de alguns concelhos existentes no reino de Portugal com os recursos administrados pela câmara de Vila Boa de Goiás, poderíamos considerá-la, até certo ponto, abastada.

Por exemplo, para o ano de 1794, computadas as rendas da câmara municipal, concluímos que o valor aproximado da receita anual teria chegado a 4.055 oitavas. Devido à metodologia informal dos cálculos que realizamos e à ausência de outros documentos, que preencheriam lacunas importantes, arriscaríamos afirmar que a receita daquele ano teria se aproximado de 5.500 oitavas, ou seja, mais de 6 contos de réis, considerando-se que, à época, uma oitava de ouro era o equivalente a 1.200 réis. Deste total, cerca de $1 / 3$ era proveniente de outros arraiais. Orçamento que poderíamos considerar folgado quando comparado com aqueles dos municípios portugueses onde, ainda segundo Nuno Monteiro, "mesmo as receitas ordinárias de municípios que eram sede de comarca, como Barcelos, Bragança, Miranda, Viana, Vila Real e Viseu, até os anos 90 do século XVIII não chegavam a dois contos de réis" (MONTEIRO, 1993: 322-323).

Como podemos ver, Vila Boa de Goiás posicionava-se estrategicamente no interior de uma rede urbana que a transformava, mesmo ao final do século XVIII, em forte atrativo tanto para as autoridades provenientes de Portugal, quanto para os grupos de poder locais. As vigorosas considerações tecidas por Mary Karasch (RUSSEL-WOOD, 1998: 22), estavam plenas de fundamento. Nada, evidentemente, comparável com o passado 
de riquezas produzidas no auge da exploração aurífera em Goiás. Estudos sobre o assunto demonstram que entre os anos de 1752 e 1761, o rendimento médio anual de Vila Boa de Goiás teria sido de 14.741 oitavas (PALACIN, 1983: 61), cerca de 17 contos de réis, não computados os valores provenientes da administração da rede de arraiais da capitania, com certeza muito mais significativas que as de 1794.

No quadro da última década do século dezoito, portanto, o conjunto dos dados apresentados nos leva a reconhecer que as dificuldades financeiras nas minas de Goiás realmente se agravaram, conduzindo a inicitivas que visavam promover ou restabelecer o equilíbrio orçamentário experimentado num passado ainda recente. Mas, a passividade parece nunca ter sido o adjetivo mais adequado para definir o comportamento dos oficiais da câmara de Vila Boa naquele final de século.

Num primeiro momento, poder-se-ia pensar, como insinua Monteiro, que as crescentes dificuldades impostas à gestão e ao governo municipais, na segunda metade do século dezoito, tenderiam a reduzir a atração pelos cargos camarários. Contudo, o que vemos são juízes ordinários, vereadores e procuradores manipulando um conjunto relevante de recursos (MONTEIRO, 1993: 323), controlando licitações de serviços e rendas públicas e intervindo na organização dos mercados locais, por meio da imposição de preços, taxas e impostos. Em síntese, detinham, realmente, o privilégio de articulação e domínio sobre uma rede urbana de dimensão significativa, o que lhes conferia uma indiscutível possibilidade de influência e poder.

\section{Agradecimentos}

Gostaria de agradecer à historiadora Lena Castelo Branco Ferreira, pela sabedoria na análise de importantes fontes inéditas sobre Goiás, ao pesquisador Magnus Roberto de Mello Pereira, pela sua visão sobre o tema, de alguma forma transferida para o presente trabalho e às refinadas sugestões de Laurent Vidal, historiador das cidades e da América. 


\section{REFERÊNCIAS BIBLIOGRÁFICAS}

AROUIVO HISTÓRICO ULTRAMARINO (AHU). Lisboa : Documentos Oficiais século XVIII.

BICALHO, M. F. B. Sertão de Estrelas. A Delimitação das Latitudes e das Fronteiras na América Portuguesa. In: Varia História, Belo Horizonte, v. 21, pp. 73-85, 1999.

BICALHO, M. F. B. Cidades e elites coloniais - redes de poder e negociação. In: Varia História, Belo Horizonte, v. 29, p. 17-38, 2003.

BOURDIEU, P., CHRISTIN, O., WILL, P-E. Sur la science de l'État. In : Actes de la Recherche en Sciences Sociales, Paris, v. 133, pp. 3-9, 2000. BRAUDEL, F. Civilisation matérielle, économie et capitalisme, XVeXVIIIe siècle (Les structures du quotidien: le possible et l'impossible). Paris : Armand Colin, 1979.

BRAUDEL, F. Civilisation matérielle, économie et capitalisme, XVeXVIIIe siècle (Le temps du Monde). Paris : Armand Colin, 1979.

CAVALCANTI, H., GUILLEN, I. Atravessando fronteiras: movimentos migratórios na história do Brasil. In: Revista Imaginário, São Paulo, v. 7, pp. 1-4, 2005. Disponível em

$<$ http://www.imaginario.com.br/artigo/revista/rev7.shtml $>$. Acesso em 03 abril 2007.

CHAUL, N. Caminhos de Goiás: da construção da decadência aos limites da modernidade. Goiânia: Cegraf, 1997.

FONSECA, C. D. Des Terres aux Villes de l'Or - Pouvoirs et territoires urbains au Minas Gerais (Brèsil, XVIIIe siècle). Paris: Fundação Calouste Gulbenkian, 2003.

FRAGOSO, J. Mercados e negociantes imperiais: um ensaio sobre a economia do império português (séculos XVII-XIX). História: Questões e Debates, Curitiba, v. 36, pp. 99-127, 2002.

FURTADO, J. F. Homens de Negócios - A interiorização da metrópole e do comércio nas Minas setecentistas. São Paulo: Hucitec, 1999.

GARCIA, D. S. C. A ocupação de terras por estrangeiros na fronteira oeste do Brasil nos primórdios da República: ocupar para desintegrar In: CONGRESSO BRASILEIRO DE HISTÓRIA ECONÔMICA E $6^{\text {a }}$ CONFERÊNCIA INTERNACIONAL DE HISTÓRIA DAS EMPRESAS, 5, 2003. Anais eletrônicos da ABPHE. Caxambu : ABPHE, 2003. Disponível 
em < http://www.abphe.org.br/congresso2003/textos.html $>$. Acesso em: 03 abril 2005.

GOUVEA, M. F. Redes de poder na América Portuguesa: O caso dos homens bons do Rio de Janeiro, ca. 1790-1822. In: Revista Brasileira de Históira, São Paulo, v. 18, pp. 297-330, 1998.

GOUVÊA, M. F. Poder, Autoridade e o Senado de Câmara do Rio de Janeiro, 1780-1820. In: Revista Tempo, Rio de Janeiro, v. 13, p. 111-156, 2000.

HOLANDA. S. B. Caminhos e Fronteiras. 3a ed.. São Paulo: Cia das Letras, 1994.

LEMES, F. L. A oeste do império - Dinâmica da câmara municipal na última periferia colonial: um estudo das relações de poder nas minas e capitania de Goiás (1770/1804). Goiânia, 2005. Dissertação (Mestrado em História) - IFCH,UFG.

LIVRO DE REGISTRO DO SENADO DA CÂMARA (LRSC). Vila Boa de Goiás : 1783-1785.

MARTINIÈRE, G. A implantação das estruturas de Portugal na América (1620-1750). In: FRÉDERIC, M. O Império Luso-Brasileiro (1620-1750). Lisboa: Estampa, 1991, pp.91-261.

MONTEIRO, N. G. Os concelhos e as comunidades. In: Antônio Manuel Hespanha (Dir.), História de Portugal - O Antigo Regime (1620-1807). Lisboa: Estampa, v. 4, 1993, p. 303-330.

NUNES, H. P. Memória da Ocupação e Colonização de Goías na Primeira Metade do Século XIX: A Visão dos Viajantes Europeus. Ciências Humanas em Revista, Goiânia, v.3, pp.71-118, 1994.

ORDENAÇÕES FILIPINAS.. In: Reprodução "fac-símile" Edição Candido Mendes de Almeida. Rio de Janeiro: 1870. Lisboa: Fundação Calouste Gulbenkian, 1990, Livro I, Título LXVIII, parágrafos 1-42.

PALACIN, L., MORAES, M. A. História de Goiás (1722-1972). Goiânia: Editora Universidade Católica de Goiás, 2001.

PALACIN, L. O século de ouro em Goiás 1722 - 1822: Estrutura e conjuntura numa capitania de minas. Goiânia: Editora Universidade Católica de Goias, 2001.

PALACIN, L. Subversão e corrupção: um estudo da administração pombalina em Goiás. Goiânia: Editora UFG, 1983.

PEREIRA, M. R. Almuthasib - Considerações sobre o direito de almotaçaria nas cidades de Portugal e suas colônias. In: Revista Brasileira de História, São Paulo, v. 42, pp. 365-395, 2001.

ROCHA, L. M. Atlas Histórico: Goiás Pré-Colonial e Colonial. Goiânia: Editora Cecab, 2001. 
RUSSEL-WOOD, A. J. R.. Centros e periferias no mundo luso-brasileiro (1500-1808). In: Revista Brasileira de História, São Paulo, v. 18, pp. 187250, 1998.

SILVA E SOUZA, L. A. Memória sobre o descobrimento, governo, população e cousas mais notáveis da Capitania de Goyaz. In: José Mendonça Teles, Vida e Obra de Silva e Souza. Goiânia: Editora UFG, 1998, pp. 71-139.

VIDAL, L. Os trilhos da história do Brasil urbano. In: Ler História, Lisboa, v. 48, pp. 75-85, 2005.

VIDAL, L. Sous le masque du colonial: naissances et "décadence " d'une vila dans le Brésil moderne : Vila Boa de Goiás au XVIIIe siècle. In : Annales HSS, Paris, v. 3, pp. 577-606, 2006.

LEMES, Fernando Lobo. Local Power and the Urban Network in the Mines of the State of Goias, Brazil. História, v.28, n.1, p.381414, 2009.

Abstract: Vila Boa de Goias was an administrative and political urban center with jurisdiction over a large region during the eighteenth century. Up till the beginning of the nineteenth century, it was the only town (vila) of Goias State, whose territory was sprinkled with many settlements, (arraiais), forming a network of small urban centers. Without the status of imperial vila, these arraiais bowed before the power of Vila Boa de Goias especially when it came to economic and political issues. In this context, what interests us most in this article is to analyze the strategies used by one urban center in being able to dominate and to guarantee the conditions and the rights to overlap its own interests upon the interests of other urban centers. Transformed into an important attraction of the local elites, this privileged political condition was the aim of great efforts and intense devotion among the municipal authorities to safeguard Vila Boa's superiority over the existent arraiais located near the mines of Goias.

Keywords: Local Power; Colonial Town; Urban Network; Portuguese Empire. 


\section{PODER LOCAL E REDE URBANA NAS MINAS DE GOIÁS}

\section{NOTAS}

${ }^{1}$ Se o governador Luiz da Cunha Menezes não foi bem sucedido ao sugerir o fim dos salários pagos aos oficiais da câmara em 1780, sete anos depois, o desembargador e intendente José Carlos Pereira, ouvidor interino na comarca de Goiás, privou-os de um privilégio praticado desde a criação de Vila Boa de Goiás. Assim, após 41 anos recebendo 200 mil réis de ordenado anual, os oficiais da câmara ficaram proibidos de continuar desfrutando desta vantagem financeira (LEMES, 2005: 92-97).

${ }^{2}$ As comarcas constituíam uma circunscrição judiciária onde atuavam os ouvidores e corregedores encarregados da administração da justiça em segunda instância (FONSECA, 2003: 18-22).

${ }^{3}$ Nas zonas de mineração da América portuguesa, tanto em Minas Gerais, como em Goiás e Mato Grosso, as aglomerações populacionais não autônomas tomaram o nome particular de arraial. O sentido original da palavra em Portugal indicava a existência de um simples acampamento, mas nas regiões de mineração coloniais serviu para designar os estabelecimentos regulares e estáveis, de várias dimensões, que não possuíam autonomia judiciária ou administrativa, permanecendo dependentes de uma vila ou cidade (FONSECA, 2003: 559).

${ }^{4}$ A palavra almotaçaria foi usada, desde o período medieval, tanto em sentido geral quanto particular, para designar a instituição ou suas atribuições e as atividades correntes do almotacé e, mais tarde, da câmara municipal, em relação ao abastecimento das cidades. Almotaçar correspondia a fiscalizar o comércio, garantindo que todos pudessem desfrutar de alimentos encontrados no mercado, racionando ou tabelando quando necessário. Foi com este sentido que a palavra chegou até o século $\mathrm{XIX}$, quando a almotaçaria era entendia como qualquer espécie ou tipo de tabelamento de preços. O termo almotacé nos parece bastante incomum, sendo consequência de uma adaptação para a língua portuguesa do nome original em árabe. O nome teria sido latinizado, no Brasil, durante o século XIX (PEREIRA, 2001: 392).

${ }^{5}$ Vandelli (1730-1815), italiano, foi o primeiro lente de química e história natural da Universidade de Coimbra após as reformas pombalinas, sendo um dos impulsionadores da criação da Academia Real das Ciências de Lisboa, em 1779.

Artigo recebido em 04/2009. Aprovado em 07/2009 